\title{
The Influence of Situational Variables on Brand Personality Choice
}

\author{
Scott Wysong ${ }^{1}$, Sri Beldona ${ }^{1}$, James Munch ${ }^{2} \&$ Susan Kleiser ${ }^{3}$ \\ ${ }^{1}$ College of Business, University of Dallas, Irving, Texas, USA \\ ${ }^{2}$ Raj Soin College of Business, Wright State University, Dayton, Ohio, USA \\ ${ }^{3}$ Neeley School of Business, Texas Christian University, Fort Worth, Texas, USA \\ Correspondence: Sri Beldona, College of Business, University of Dallas, Irving, TX, USA. Tel: 1-972-721-4149. \\ E-mail: sbeldona@udallas.edu
}

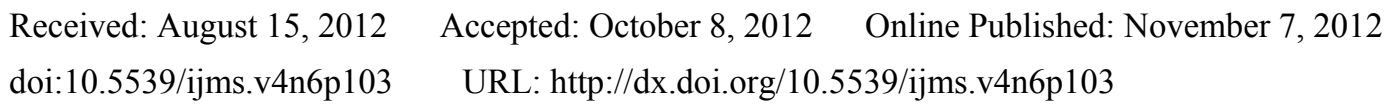

\begin{abstract}
The goal of this research is to investigate whether or not consumers select brands (and their brand personality) based on two important situational variables: social visibility and situational involvement. An experimental study was conducted in which two hundred and thirty-nine respondents were randomly assigned to one of four situations and asked via a self-administered questionnaire to describe the beer, with regard to its brand personality, that they would purchase in that situation. Situations were either high or low in social visibility and high or low in situational involvement resulting in a 2 X 2 factorial design. Three-way interaction effects between the situational variables (i.e., situational involvement and social visibility) and an individual variable (i.e., brand loyalty) were discovered. The results indicate that depending on the situation and an individual's brand loyalty, consumers will seek different types of brands (personality-wise). Thus, this research should help brand managers further understand how their brands are perceived and consumed.
\end{abstract}

Keywords: consumer behavior, branding, social visibility, situational involvement

\section{Introduction}

Understanding how an individual 'sees' a brand is of paramount importance in today's marketplace. In almost every product category, consumers prefer branded versus unbranded products. While there are a myriad of reasons as to why consumers buy the brands that they do, the image of the brand cannot be overlooked. Many times, consumers buy a brand because they identify with or simply like a brand's image. Thus, marketers must continually try to examine how consumers perceive their brand's image. To help understand brand image perceptions, researchers have turned to the concept of brand personality within the last fifteen years. With this approach, consumers are asked to think of the brand as if it was a person. By having consumers rate brands on human characteristics, such as honest, wholesome, daring, upper-class, tough, etc., marketing researchers and practitioners can further explore how and why consumers 'see' brands the way they do.

While previous research has determined that brands do have personalities (Aaker, 1997; Aaker, 1999; Wysong, Munch, \& Kleiser, 2002; Beldona \& Wysong, 2007), little research has examined whether or not consumers seek a brand (with a personality) based on the situation (Sung, 2011). While there are a number of variables that can define a situation, this research examines two such variables: social visibility and situational involvement. Both social visibility and situational involvement have been found to influence consumer behavior by previous researchers. Thus, the goal of this research is to investigate whether or not individuals select brands (and their brand personality) based on the social visibility and involvement of the situation.

An experimental study was conducted in which two hundred and thirty-nine respondents were randomly assigned to one of four situations and asked, via a self-administered questionnaire, about the type of beer (from a brand personality perspective) that they would purchase in that situation. Situations were either high or low in social visibility and high or low in situational involvement, resulting in a 2 X 2 factorial design.

The results of this research indicate that the social visibility and involvement of a situation can influence the type of brand personality that consumers seek in that situation. Specifically, a three-way interaction between social visibility, situational involvement and a consumer's brand loyalty, within the category, was discovered. Hence, marketers must continually strive to understand as much as they can about the context in which their product is 
consumed. With this information, marketers can create strategies that best fit a given situation and/or encourage consumers to purchase their brand in that situation.

\section{Theoretical Background}

Situational influences can and do explain variance in consumer behavior (Belk, 1975). While researchers have debated what variables should comprise a situation (Barker, 1975; Belk, 1975; Russell \& Mehrabian, 1976; Wicker, 1975), many researchers agree that consumer behavior must be understood in its situational context, because people act differently in different situations (Mihic \& Kursan, 2010). The same person may act sincere and caring at home with their family, competent and reliable at work, or tough and outrageous at a nightclub with friends. Thus, the variables that make up each situation dictate the behavior. While Belk (1975) insisted that situational definitions be as specific as possible, others such as Wicker (1975) advocated a broader categorization of situational variables. The debate over which situation taxonomy to use is beyond the scope of this research. However, two groups of fundamental attributes that should be included in any research of situations are the setting (i.e., the other people present, physical surroundings, date, time, etc.) and the motives (i.e., the reasons for being in the situation) (Belk, 1975). For the purposes of this research, the variable related to the setting that will be examined is social visibility. Specifically, situations will be considered either public or private. With regard to motives, situational involvement will be investigated. Specifically, situations will be considered either high or low in involvement.

\subsection{Social Visibility}

According to Bearden and Etzel (1982), a public product is "one that other people are aware you possess and use. If they want to, others can identify the brand of the product with little or no difficulty" (p.186). On the other hand, Bearden and Etzel (1982) define a private product as "one used at home or in private at some location. With the exception for your immediate family, people would be unaware that you own or use the product" (p. 186). In this research, we are concerned with where the product is consumed: in public or in private. Using Bearden and Etzel's (1982) definition of public and private products, we can form definitions of public and private situations. Herein, public situations will be considered those in which people, other than your immediate family, are present. Based on this definition, in public situations, product consumption is more conspicuous or socially visible than in private situations.

Because public and private situations are so fundamentally different, people are likely to act differently in each (Browne \& Kaldenberg, 1997). One reason for the behavioral differences in public and private situations is the influence of reference groups (Bearden \& Etzel, 1982). When other people are present (public situation), they impact our decisions (Fitzmaurice \& Comegys, 2006). People are more prone to disapproval from others (with regard to product/brand choice) in high socially visible (public) situations than in low socially visible (private) situations. For instance, Witt and Bruce (1972) found greater group cohesiveness in brand choice in products consumed publicly than those consumed privately.

When the product is visible, consumers may try to fit into the group often looking to the group for guidance (Aqueveque, 2006). According to Mowen and Minor (1998), public situations are affected by the social comparison process, which they define as "the process through which people evaluate the 'correctness' of their opinions, the extent of their abilities and the appropriateness of their possessions" (p. 489). As a result, in social situations, people might look for feedback from the others present. If positive, they are more likely to maintain the status quo. However, if they receive negative feedback from others present, they may modify their behavior. Consequently, a person can act one way in a public situation and a totally different way in a private situation, due to the varying degrees of social visibility.

The type of brand (personality-wise) that is consumed should be affected by the social visibility of the situation. A brand's personality describes the brand, not only to the user, but also to the others present in the situation. Based on the theory outlined above, public situations differ from private situations in their social visibility. Hence, the brand personality dimensions should be enhanced in a public situation compared to a private one. Thus, it is hypothesized;

H1: Individuals will intend to purchase a brand with more brand personality when they are going to consume a brand in a public situation compared to a private one.

\subsection{Involvement}

According to Mowen and Minor (1998), involvement is the "perceived personal interest and/or interest consumers attach to the acquisition, consumption and disposition of a good, a service, or an idea" (p. 64). Petty, Cacioppo, and Schumann (1986) found that consumers used different cognitive processes, or routes to 
persuasion (central vs. peripheral), in high versus low involvement conditions. According to Schiffman and Kanuk (1997), as the "message becomes more personally relevant (that is, as involvement increases), people are more willing to expend the cognitive effort to process the message arguments" (p. 217). Consumers in high involvement conditions have higher levels of excitement, energy, and arousal, and they think more about the object or event of interest (Wilkie, 1994). More recently, Bauer, Sauer, and Becker (2006) found a significantly positive relationship between consumer decision-making and the nature of product involvement. Thus, it is hypothesized;

H2: Individuals will intend to purchase a brand with more brand personality when they are going to consume a brand in a high involvement situation compared to a low involvement one.

Because situations rarely have one component (e.g., just social visibility or just situational involvement), an interaction between the situational variables should occur. With social visibility and situational involvement each having two levels, there are four possible situations: Public/High Involvement, Public/Low Involvement, Private/High Involvement, Private/Low Involvement. Thus, it is hypothesized;

H3: Individuals will intend to purchase brands with different levels of brand personality across the four situations.

Figure 1 provides a graphical depiction of the proposed relationships. As illustrated, an individual seeks a brand with a desired brand personality. Moreover, there are situational influences, including the situation's social visibility and involvement, which should affect an individual's desired brand personality.

Because different people respond to situations differently, individual variables were introduced to this research, as well. The individual variables to be studied include an individual's enduring involvement with the product category of interest, enduring involvement with the behavior of interest, brand loyalty, importance of brand image, and category familiarity.

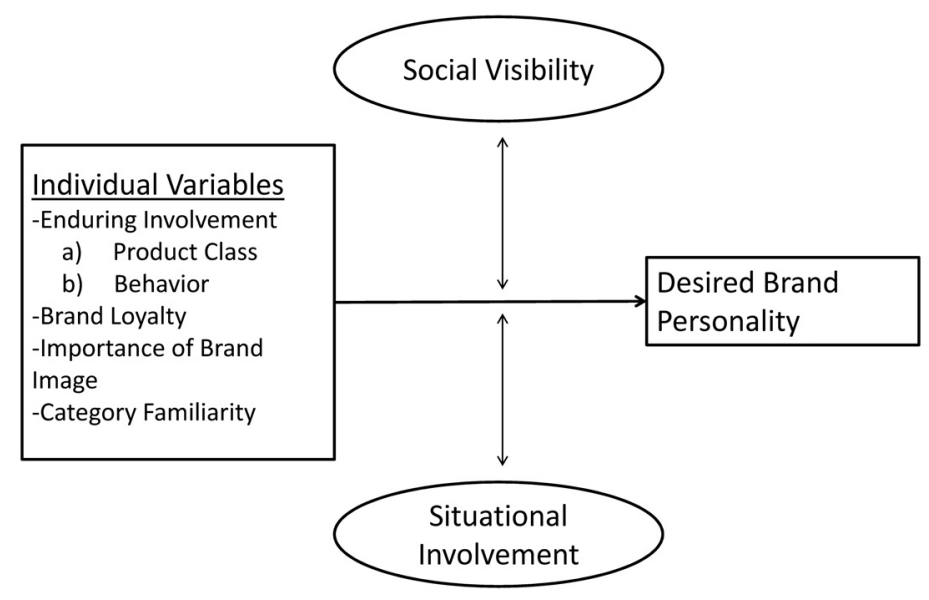

Figure 1. A model of the proposed effects of individual and situational factors on one's desired brand personality

\section{Methodology}

\subsection{Product}

In choosing the product category, four criteria were used. First, it was necessary to have a product that was familiar to the sample (undergraduate students). Second, a product category with a number of different brands was desired. Third, a product that could be both consumed publicly and privately was required. Fourth, it was believed that an emotional or feeling product would be better for eliciting brand personality perceptions. A pool of products was selected from Ratchford's (1987) work. Using the Foote, Cone, and Belding (FCB) grid, Ratchford (1987) empirically classified a large number of products with many respondents over several studies. His work demonstrated both reliability (alpha values ranged from 0.64 to 0.77 ) and validity (content, trait, and discriminant). For the research herein, groups of undergraduate students were asked about their familiarity with 
several products in Ratchford's modified FCB grid. Of concern were products from the "feel" quadrants, which involve social acceptance and ego gratification according to Ratchford (1987). Products that fall into these quadrants include cigarettes, beer, fast food, perfume and jewelry. Based on these informal discussions and the criteria discussed above, beer was chosen as the product category for this research.

\subsection{Setting}

As previously mentioned, two situational variables were chosen for this research: social visibility and situational involvement (each with a high and low level). As a result, this study involved a total of four situations. In the social visibility conditions, the situation was described by the phrase "at home by yourself" in the low level (private situation) and "at a party at a friend's house" in the high level (public situation). These descriptions are in accordance with Bearden and Etzel's (1982) definition. Before the situational involvement conditions were chosen, a small focus group was conducted with potential respondents (undergraduate students). Group members were asked to identify situations in which they drank beer at home by themselves and situations in which they drank beer at a party at a friend's house. The common theme between the public and private situations was sports. The potential respondents believed that one could drink beer at home while watching sports or at a party at a friend's house while watching sports. Consequently, the high involvement situation for this research was "Your favorite team is playing in the championship game," while the low involvement situation was "Your favorite team is playing in a preseason game."

\subsection{Pretest}

The goal of the pretest was to determine if the situation manipulations were, in fact, distinct with regard to the treatment variables: social visibility and situational involvement. Fifty undergraduate students at a large southwestern university were randomly assigned to one of two versions of a self-administered survey.

The four situations discussed previously were broken down into their respective components for the purposes of this pretest. Each version (A or B) of the pretest survey contained two situations: a situation with a social visibility variable (high or low) and a situation with an involvement variable (high or low). The first situation dealt with social visibility. Version A of the pretest contained the situation "You are watching a pro football game at home by yourself," while Version B's situation was "You are watching a pro football game at a party at a friend's house."

Respondents were asked to indicate their perceptions of the situation by checking the appropriate space on each of six scale items (each item was a 7-point semantic differential). These scale items were designed to measure the social visibility of the situation. Examples of scale items included "A very social situation/Not a very social situation" and "A very public situation/A very private situation."

Before this pretest was administered, an exhaustive search for an existing social visibility scale was conducted. However, most of the existing sociological and psychological work, with regard to social situations, dealt with self-monitoring and social support structures. For this research, the initiative was to simply find a scale to measure whether a situation was public (high social visibility) or private (low social visibility). Therefore, a social visibility scale was developed specifically for this research (See Appendix A).

Based on the work of Tedeschi (1986), each item in our social visibility scale attempted to capture how an individual would act, think or feel in a public situation or private situation. For instance, Tedeschi (1986) proposed that in public situations, a person's behavior is more observable by others. In addition, he asserted that people try not to display emotions or give out too much private information about themselves in public situations. Similarly, people are more likely to act in the interest of the group (versus in their self-interest) when in public (Tedeschi, 1986).

Once all respondents were finished with the social visibility scale, respondents were instructed to read the next situation, which contained the situational involvement component. Version A contained the high involvement condition "Your favorite team is playing for the championship" while Version B contained the low involvement condition "Your favorite team is playing in a preseason game." Respondents were then asked to answer four scale items ( 1 = Strongly Disagree to 7 = Strongly Agree $)$ that were developed to measure the involvement of the situation. Examples of items included "This game would be very important to me" and "I would be very involved in this game."

Similar to the case with social visibility, it was difficult to find an involvement scale that fully met the needs of this research. Many of the existing scales measured a consumer's involvement with a product class. However, this study was concerned with how involved a person felt in a situation. Therefore, it was determined that constructing a scale tailored to the situations used in this research would be more appropriate. Based on work by 
Zaichkowsky (1985), the concepts of "important" and "essential" were integrated into two scale items. The remaining two scale items were developed in an effort to capture the concepts of anticipation (for the situation) and overall involvement (in the situation). The result is a scale that incorporates several components of situational involvement (See Appendix B).

\subsection{Main Study}

Undergraduate students $(\mathrm{n}=335)$ at a large public university in the Southwest were randomly assigned to one of four situations. As discussed previously, these four situations were comprised of two variables: social visibility (high vs. low) and situational involvement (high vs. low). Thus, the design of this study was a $2 \times 2$ factorial experiment.

Respondents were given a self-administered written survey. Before beginning the first section, respondents were told that the survey intended to find out about brands of beer and they were asked to think about their given situation and respond to the scale items as though the situation was real. Respondents were informed that they would have a chance to indicate their purchase frequency and attitudes toward beer at the end of the survey. Respondents under the age of 21 were excused from the classroom and did not participate in the survey.

After reading their assigned situation (See Appendix C for all four situation descriptions), respondents were first asked to "Please indicate the extent to which each trait describes the beer that you would purchase in this situation." Using 7-point Likert scales $(1=$ Not at all Descriptive to $7=$ Extremely Descriptive), respondents indicated their "desired" beer using each of Aaker's (1997) fifteen brand personality facets from her Brand Personality Scale (BPS). Aaker's (1997) BPS was selected for this research because it was developed using rigorous methodology in an effort to ensure its reliability and validity. Aaker (1997) found that, through factor analysis, these fifteen brand personality facets represented five brand personality dimensions: Sincerity, Excitement, Competence, Sophistication, and Ruggedness.

After indicating the brand personality of the beer that they would purchase in their assigned situation, respondents were given a number of scale items pertaining to the individual variables of interest in this study. The first variable covered in this part of the survey was an individual's enduring involvement with the product category: beer. A total of eight Likert scale items $(1=$ Strongly Disagree to $7=$ Strongly Agree $)$ were used to construct this scale. The first six items were adopted from Lastovicka and Gardner's (1979) Components of Involvement (CP) Scale (no reliabilities were reported from the authors.). These six items were designed to measure a person's familiarity and interest with a product class. Examples of scale items included "Beer is a product that interests me" and "Beer is a product that I could talk about for a long time." The last two scale items were taken from Laurent and Kapferer (1985). One scale item measured the hedonic/pleasure component of involvement while the other represented the interest facet. While using a proven enduring involvement scale in its entirety would have been preferred, the ad-hoc approach taken was necessary. Parts of the two scales were combined to cover the varying aspects of involvement in a concise manner, without creating respondent apprehension (with regard to indicating their involvement with an alcohol product).

Because the situational manipulations in this study dealt with watching sports, it was necessary to ask respondents about their attitudes toward sports. Eleven 7-point Likert scale items $(1=$ Strongly Disagree to 7 $=$ Strongly Agree) were created to measure one's enduring involvement with the situational behavior: sports. Three of the scale items were adopted from Mittal's (1995) Modified Consumer Involvement Profile (Modified CIP) for product class involvement (construct reliability $=0.75$ ). The other eight items were created for this research. Examples of scale items included "I usually talk about sports with other people" and "I follow my favorite teams very closely." These scales were constructed for this research, versus using an existing scale, because following sports is a unique phenomenon. Unlike most traditional products and services, consumers can be very involved in sports without ever purchasing anything. Because many of the existing scales dealt specifically with a product or purchase decision, scales specific to sports were developed for this research.

To capture brand loyalty, respondents were directly asked if they were brand loyal with beer (YES/NO). To measure an individual's importance of brand image with regard to beer, three 7-point Likert scale items were used $(1=$ Strongly Disagree to $7=$ Strongly Agree $)$. Two of the items were taken from Traylor and Joseph's (1984) General Scale to Measure Involvement (GSMI). These scale items were "You can tell a lot about a person by the beer he or she chooses" and "Beer helps me express who I am." The third scale item was created for this research: "Choosing a beer for the right situation takes a lot of careful thought." To measure category familiarity, respondents were asked, "How often do you purchase beer?" Respondents then checked one of five spaces ranging from "Never" to "Over ten times a month." Finally, demographic information (age and gender) was collected. 


\subsection{Manipulation Check}

After completing the survey in the main study described above, a subset of thirty-nine respondents (randomly chosen out of the original 335 respondents) were asked to complete the social visibility and situational involvement scales used in the pretest. Hence, respondents indicated their perceptions of their assigned situation (with regard to social visibility and situational involvement). The purpose of this manipulation check was to verify that actual respondents believed that the situations did differ with regard to social visibility and situational involvement. A subset of the respondents (versus all respondents) was used for this manipulation check due to the length of the survey. Asking all of the respondents to complete the additional pages may have resulted in respondent fatigue for the entire sample.

\section{Results}

\subsection{Pretest}

The goal of the pretest was to determine if the situation manipulations were distinct, with regard to social visibility and situational involvement. To measure the difference between the social visibility manipulations ("at home by yourself" as the low condition versus "at a party at a friend's house" as the high condition), the mean social visibility rating for each condition was calculated (average of the six scale items). With the semantic differential scale items, numbers were arbitrarily assigned to each space (the entire scales were reversed so that the higher the score, the higher the social visibility or "publicness"). The social visibility scale proved to be reliable (Cronbach's alpha $=0.95$ ) and the results revealed that the mean social visibility rating for the public situation was 5.15 and the mean for the private situation was 1.68. Using a one-tailed t-test, it was concluded that the high social visibility (public) condition mean was significantly greater than the low social visibility (private) condition mean $(\mathrm{p}<0.01)$.

To test the difference between the high involvement situation manipulation (championship game) and the low involvement situation manipulation (preseason game), the mean involvement rating for each condition was calculated (average of the four scale items). The situational involvement scale had acceptable reliability $($ Cronbach's alpha $=0.96)$ and the results revealed that the mean involvement rating for the high involvement situation was 5.51 and the mean for the low involvement situation was 2.97. Using a one-tailed t-test, it was concluded that the high involvement condition mean was significantly greater than the low involvement condition mean $(\mathrm{p}<0.01)$.

The social visibility and situational involvement scales were tested for their discriminant validity as well. A principal components factor analysis with varimax rotation was run on all of the items of the aforementioned two scales. The results indicated that the social visibility scale items loaded on one factor, while the situational involvement scale items loaded on a separate factor. With the items of the scales loading on distinct factors, the scales can be considered robust, with regard to discriminant validity.

\subsection{Manipulation Check}

While the results of the pretest confirmed that the situational components were indeed different, it was still necessary to make sure that those who participated in the actual study felt that the situations, presented in their entirety, were different. Thus, using the exact same social visibility and situational involvement scales, two separate one-tailed t-tests were run. Similar to the pretest, both scales had acceptable reliability (social visibility: Cronbach's alpha $=0.91$, situational involvement: Cronbach's alpha $=0.94)$. The first t-test revealed that the difference between the public $($ mean $=5.00)$ and private $($ mean $=3.71)$ situations was in fact significant $(\mathrm{p}=$ $0.01)$. The second t-test revealed that the high involvement situation (mean $=3.71$ ) and low involvement situation $($ mean $=2.77)$ were also significantly different $(p<0.05)$. Similar to the pretest results, both the social visibility scale and situational involvement scale proved to have discriminant validity (via separate factor loadings when a principal factor analysis with varimax rotation was run on all of the individual scale items).

\subsection{Descriptive Statistics}

Individuals who indicated that they 'Never' drank beer were excluded from the analysis resulting in a final sample of 239. The average age of the sample was 27 and $49.5 \%$ were male. The number of respondents randomly assigned to each situation was relatively equal. In addition, there were no statistically significant differences between the cells (situations) for any of the individual variables of interest.

For the brand personality ratings, Reliability had the highest rating across all situations with a mean of 4.67 (std. dev. $=2.0$ ). For all of the brand personality means, please see Table 1 . For the individual variables, $58 \%$ indicated that they were brand loyal with regard to beer. In addition, the average ratings for the other individual 
variables were as follows; Enduring Involvement with Beer mean $=4.35$ (std. dev. $=1.3$ ), Enduring Involvement with Sports mean $=4.21$ (std. dev. $=1.9)$, and Importance of Brand Image mean $=2.85($ std. dev. $=1.3)$.

Table 1. Descriptive statistics for brand personality ratings

\begin{tabular}{llll}
\hline $\begin{array}{l}\text { Brand } \\
\text { Personality } \\
\text { Trait }\end{array}$ & N & Mean & $\begin{array}{l}\text { Standard } \\
\text { Deviation }\end{array}$ \\
\hline Reliable & 237 & 4.67 & 1.99 \\
Successful & 237 & 4.45 & 2.03 \\
Up-to-Date & 237 & 4.31 & 1.96 \\
Spirited & 237 & 4.25 & 1.86 \\
Cheerful & 237 & 4.18 & 1.82 \\
Upper-Class & 237 & 4.02 & 2.00 \\
Outdoorsy & 237 & 3.92 & 1.97 \\
Imaginative & 237 & 3.89 & 1.95 \\
Tough & 237 & 3.86 & 1.97 \\
Daring & 237 & 3.73 & 1.82 \\
Intelligent & 237 & 3.68 & 2.03 \\
Honest & 237 & 3.64 & 1.88 \\
Wholesome & 237 & 3.64 & 1.80 \\
Down-to-Earth & 237 & 3.57 & 1.78 \\
Charming & 237 & 3.44 & 1.91 \\
\hline
\end{tabular}

\subsection{Scales}

\subsubsection{Brand Personality}

As mentioned throughout, the brand personality scale used herein was based on Aaker's BPS (1997). In an effort to replicate Aaker's (1997) work, factor analysis was performed to reduce the fifteen brand personality facets down to five dimensions. Principal components factor analysis with varimax rotation was used and a five-factor solution was sought.

The five factors in this research explained $75.5 \%$ of the variance. However, there were several differences between Aaker's work and this study. For one, Cheerful loaded on SINCERITY in Aaker's (1997) work, yet it loaded on EXCITEMENT in this research. Secondly, Up-to-Date loaded on EXCITEMENT in Aaker's work, yet COMPETENCE in this research. Third, Reliable loaded on COMPETENCE in Aaker's work, yet SINCERITY in this research. Fourth, the traits, Intelligent and Successful, were considered part of COMPETENCE with Aaker (1997), yet SOPHISTICATION herein.

Overall, the factor loadings in this research were relatively high $(>0.60)$ with the exception of cheerful $(0.49)$ and reliable (0.52). Despite the slightly different loadings, Aaker's (1997) dimension names were kept because of their relative similarity. To ensure that the traits that loaded on each dimension were internally consistent, each group of traits was tested for reliability. All Cronbach's alphas for each dimension were considered acceptable (> $0.70)$.

To compute the brand personality dimensions, each trait's factor loading was used as a weight. Consequently, each respondent's brand personality rating for a trait was multiplied by the factor loading for that trait. Then, for each dimension, the weighted traits that loaded on that dimension were summed and then divided by the number of traits loading on that dimension.

\subsubsection{Individual Variables}

The scales for Enduring Involvement with Beer, Enduring Involvement with Sports, and Importance of Brand Image were analyzed for reliability and discriminant validity. With regard to reliability, all three scales were found to have acceptable reliability (Enduring Involvement with Beer Scale Cronbach's alpha $=.87$; Enduring Involvement with Sports Scale Cronbach's alpha $=.97$; Importance of Brand Image Scale Cronbach's alpha $=.91$ ). To test for discriminant validity, principal components factor analysis with varimax rotation was run on the scale items for the individual variables: Enduring Involvement with Beer, Enduring Involvement with Sports, 
and Importance of Brand Image. The results indicated that each scale's items loaded on a separate and distinct factor (a total of three factors were found). Thus, the scale items for each construct measured only that construct.

\subsection{Hypotheses Testing}

To test the three hypotheses, a MANCOVA was run. In this analysis, the dependent measures were the brand personality dimensions: SINCERITY, COMPETENCE, EXCITEMENT, SOPHISTICATION, and RUGGEDNESS. MANCOVA was used because of the existing interrelationships between these dependent variables; Correlations revealed that bivariate correlations between each of the five dimensions were significant $(\mathrm{p}<.001)$.

While the experimental manipulation was a 2 X 2 factorial, Brand Loyalty was considered a blocking factor in this analysis. Consequently, there were three treatment variables (Social Visibility, Situational Involvement, and Brand Loyalty), with two levels each, resulting in a 2 X 2 X 2 design. The covariates were an individual's Enduring Involvement with Beer, Enduring Involvement with Sports and Importance of Brand Image. A Type III Sum of Squares full factorial was the designated model in this analysis.

The Box's M test $(p=0.11)$ revealed that the assumption of homogeneity was met. Next, the multivariate results were analyzed (see Table 2). There was overall significance $(p<0.05)$ for Social Visibility, Brand Loyalty, Importance of Brand Image and the interaction between Social Visibility, Situational Involvement, and Brand Loyalty.

Table 2. MANCOVA results

\begin{tabular}{|c|c|c|c|c|c|}
\hline Source & Dependent Variable & $\begin{array}{l}\text { Type III } \\
\text { Sum of } \\
\text { Squares } \\
\end{array}$ & df & $\mathbf{F}$ & p-value \\
\hline \multirow[t]{5}{*}{ Corrected Model } & SINCERITY & 503.04 & 10 & 3.93 & .00 \\
\hline & EXCITEMENT & 546.14 & 10 & 3.09 & .00 \\
\hline & COMPETENCE & 81.43 & 10 & 2.23 & .02 \\
\hline & SOPHISTICATION & 1200.67 & 10 & 5.45 & .00 \\
\hline & RUGGEDNESS & 366.08 & 10 & 4.99 & .00 \\
\hline \multirow[t]{5}{*}{ Intercept } & SINCERITY & 634.04 & 1 & 49.55 & .00 \\
\hline & EXCITEMENT & 933.54 & 1 & 52.82 & .00 \\
\hline & COMPETENCE & 188.95 & 1 & 51.84 & .00 \\
\hline & SOPHISTICATION & 1207.93 & 1 & 54.85 & .00 \\
\hline & RUGGEDNESS & 167.11 & 1 & 22.76 & .00 \\
\hline Importance of Brand & SINCERITY & 142.82 & 1 & 11.16 & .00 \\
\hline \multirow[t]{4}{*}{ Image } & EXCITEMENT & 282.86 & 1 & 16.00 & .00 \\
\hline & COMPETENCE & 24.37 & 1 & 6.69 & .01 \\
\hline & SOPHISTICATION & 860.46 & 1 & 39.07 & .00 \\
\hline & RUGGEDNESS & 121.53 & 1 & 16.55 & .00 \\
\hline \multirow[t]{5}{*}{ Social Visibility } & SINCERITY & 29.66 & 1 & 2.32 & .13 \\
\hline & EXCITEMENT & .68 & 1 & .04 & .85 \\
\hline & COMPETENCE & 16.56 & 1 & 4.54 & .03 \\
\hline & SOPHISTICATION & 38.23 & 1 & 1.74 & .19 \\
\hline & RUGGEDNESS & 77.78 & 1 & 10.59 & .00 \\
\hline \multirow[t]{5}{*}{ Brand Loyalty } & SINCERITY & 49.61 & 1 & 3.88 & .05 \\
\hline & EXCITEMENT & 3.56 & 1 & .20 & .65 \\
\hline & COMPETENCE & 1.60 & 1 & .44 & .51 \\
\hline & SOPHISTICATION & 185.46 & 1 & 8.42 & .00 \\
\hline & RUGGEDNESS & 3.42 & 1 & .47 & .50 \\
\hline Social Visibility * & SINCERITY & 47.75 & 1 & 3.73 & .06 \\
\hline Involvement $*$ & EXCITEMENT & 21.00 & 1 & 1.19 & .28 \\
\hline \multirow[t]{3}{*}{ Brand Loyalty } & COMPETENCE & 4.34 & 1 & 1.19 & .28 \\
\hline & SOPHISTICATION & 3.51 & 1 & .16 & .69 \\
\hline & RUGGEDNESS & 25.75 & 1 & 3.51 & .06 \\
\hline
\end{tabular}


However, Situational Involvement $(p=0.64)$, Enduring Involvement with Beer $(p=0.06)$, Enduring Involvement with Sports $(p=0.22)$, and the two-way interaction between Situational Involvement and Social Visibility $(\mathrm{p}=0.68)$ were not significant. Thus, there is no support for $\mathrm{H} 2$ and $\mathrm{H} 3$.

Examining $\mathrm{H} 1$ closer, we found the overall model for each dependent variable to be significant $(\mathrm{p}<0.05)$. Looking at the between-subjects effects for Social Visibility, significant differences were found between the high condition (at a party) and the low condition (at home) for COMPETENCE $(\mathrm{p}=0.03)$ and RUGGEDNESS $(\mathrm{p}<$ 0.01). For COMPETENCE, the means were 4.04 and 4.56 for the high condition and low condition, respectively. For RUGGEDNESS, the means were 2.93 and 3.50 for the high condition and low condition respectively. With COMPETENCE and RUGGEDNESS, the ratings were higher in the low social visibility condition (home) than in the high social visibility condition (party). This was opposite of what was expected, and thus, H1 cannot be confirmed either.

\subsection{Other Findings}

Looking at the between-subjects effects, an individual's Importance of Brand Image positively influenced their desired level of brand personality for all five dimensions (all $\beta$ s were positive, all $p$-values $<0.05$ ). So, the more an individual emphasized brand image, the stronger their desired brand personality.

There were also main effects for Brand Loyalty. Specifically, there were significant differences between brand loyal and brand-switching respondents for SINCERITY $(p=0.05)$ and SOPHISTICATION $(p<0.01)$. The means for SINCERITY were 2.64 for brand loyal respondents and 2.34 for brand-switching respondents. The means for SOPHISTICATION were 3.08 for brand loyal respondents and 2.66 for brand-switching respondents. So with both SINCERITY and SOPHISTICATION, brand loyal respondents had significantly higher ratings than brand-switching respondents.

Although proposed, an interaction between Social Visibility and Situational Involvement did not occur. However, the multivariate results did indicate that three-way interaction effects were present between Social Visibility, Situational Involvement, and Brand Loyalty $(p=0.01)$. Examining the between-subjects results, there were two brand personality dimensions with three-way interaction effects: SINCERITY $(\mathrm{p}<.05$; two-tailed) and RUGGEDNESS ( $p<0.05$; two-tailed).

\section{Discussion, Limitations and Future Research}

\subsection{Discussion}

The brand personality dimensions were expected to be enhanced in a socially visible situation. When others are present (in public), a consumer may want those individuals to perceive him or her in a particular way (e.g., rugged, sophisticated, competent, etc.). Of course, the audience present will influence the way a consumer wants to be perceived. As mentioned before, a person may want to be viewed as tough and rugged around friends, sincere and caring at home with family, and sophisticated when out on a date. While each person may seek a different brand personality for the situations in this research, it was still expected that people would seek a stronger personality (i.e., rated higher on ruggedness, sophistication, competence, etc.) in a public versus a private situation.

However, the results of this study indicated that people preferred beers with more competence and ruggedness at home by themselves (private situation) rather than at a party at a friend's house (public situation). This was counter to what was hypothesized. Perhaps this occurred because when drinking beer at home by one's self, the emphasis is placed on the beer. In contrast, when going to a party at a friend's house, other factors (e.g., what to wear, when to show up, etc.) might become more prevalent.

Consumers were also expected to seek or desire more personality in the high involvement situation than in the low involvement situation. When their team was playing in an important game (championship), it was thought that people would buy a special beer for the "big" occasion. However, this was not the case; No significant differences were found between the high (championship game) and low (preseason game) conditions. Perhaps when buying beer to watch their favorite team, individuals buy the same type of beer (personality-wise) regardless of the level of game (championship vs. preseason). In contrast, they may buy a different type (personality-wise) of beer for other occasions (e.g., barbecuing, going to the beach, etc.).

It is believed that those who are brand loyal often think of their product differently than those who are not brand loyal (brand switchers). For example, in many cases, brand loyal consumers are more committed and passionate about their brands. Consequently, as the results herein confirmed, brand loyal and non-brand loyal (brand-switching) consumers desired different levels of brand personality. Specifically, the results indicated that brand loyal consumers rated their brands higher in sincerity and sophistication than brand-switching consumers. 
Perhaps these brand personality dimensions are the reasons for consumer brand loyalty. In other words, these brand loyal consumers are brand loyal because they have found a brand with the right amount of sincerity and/or sophistication.

While interaction effects between the two situational variables (social visibility and situational involvement) were not found, there were three-way interaction effects between situational involvement, social visibility, and brand loyalty for two brand personality dimensions: sincerity and ruggedness. While several significant differences were discovered, two differences stand out. First, with brand loyal consumers in the high situational involvement condition, there was little difference in the sincerity ratings between the high social visibility and low social visibility conditions $(\mathrm{p}>0.05)$. Yet, in the low situational involvement condition, brand loyal consumers in the low social visibility condition had higher $(\mathrm{p}=0.01)$ sincerity ratings than brand loyal consumers in the high social visibility condition. Hence, future research should explore why brand loyal consumers would desire more sincerity when in the low involvement/low social visibility condition (watching a preseason game at home) than in the low involvement/high social visibility condition (watching a preseason game at a party at a friend's house).

The other three-way interaction of interest pertains to ruggedness. In the high social visibility and high situational involvement condition, there was no difference between the brand loyal and brand-switching consumers with regard to ruggedness $(\mathrm{p}>0.05)$. However, in the high social visibility and low situational involvement condition, brand loyal consumers desired significantly more ruggedness than brand-switching consumers $(\mathrm{p}=0.02)$. Hence, future research should examine why brand loyal consumers desire more ruggedness than brand-switching consumers when in the high social visibility/low involvement condition (watching a preseason game at a party at a friends' house).

\subsection{Limitations}

There are several limitations to this research that must be noted. First, the differences between self-reported and actual behavior are recognized. While a field study would have contained more external validity, it was believed that a survey in a controlled environment was more appropriate in this case given the complex nature of measuring brand personality.

Another possible limitation involves the four situation manipulations. Some may feel that there is not enough variability in the situations. While the situations were similar in nature, this was exactly the goal. Having very distinct situations such as "camping with friends" and "attending a fancy wedding" similar to what Aaker (1999) investigated would have no doubt produced different brand personalities. However, one of the aims of this research was to compare desired brand personalities in public versus private situations. Finding a product that is consumed both publicly and privately and constructing realistic situation manipulations was a challenge. Adding situational involvement as a variable made it even more difficult. Furthermore, we wanted the descriptions to be as consistent as possible (with the exception of the manipulation) to eliminate any possible extraneous sources of variability in the data. Although similar, all four situations did manifest the desired situational variables as the pretest and manipulation check results revealed. In addition, informal focus groups prior to the research revealed that respondents believed all four situations to be realistic.

Other possible limitations include the respondent selection and the use of only one product category. Some researchers criticize the use of undergraduates in academic research. Given the product category (beer), using undergraduates as respondents does not appear to weaken the study. As previously mentioned, informal focus groups revealed that a number of undergraduates did purchase, consume, and have at least some knowledge of the product category. While only one product category was used, this was necessary due to the exploratory nature of this study.

\subsection{Future Research}

The results of this study provide exciting opportunities for brand personality research in the future. While this study looked at the influence of situational involvement and social visibility on one's desired brand personality, other situational variables could be examined in future studies. For instance, Belk (1975) believed that temporal variables (e.g., date, time, etc.) could be used to categorize a situation. In addition, he advocated that researchers measure individuals' moods due to their influence in a situation. So, mood and other possible individual variables could be examined in future research, as well. While this research was confined to one product category, future research should look at other categories and compare the relationships between different types of categories. Due to its robustness, Ratchford's (1987) work provides a template for possible future products. For instance, beer, according to Ratchford (1987), is a low involvement/feeling product. Would the results differ if a thinking product (e.g., aspirin) were used? What about a high involvement product (e.g., perfume)? 
While a number of researchers have investigated brand personality in recent years, more work is needed to further our knowledge of this intricate phenomenon of consumer behavior. As Podoshen and Andrzejewski (2012) recently discovered, conspicuous consumption still influences consumer decision-making. Moreover, recent studies have confirmed that consumers still base purchase intentions on a brand's personality (Akin, 2011), and in turn, brand personality still contributes to a brand's equity (Folse, Netemeyer, \& Burton, 2012). So, brand personality is still a relevant topic, and hopefully, the research results reported herein can provide a platform to further the academic and practitioner understanding of the role of a brand's personality in different consumption situations.

\section{References}

Aaker, J. (1997). Dimensions of brand personality. Journal of Marketing Research, 34, 347-56. http://dx.doi.org/10.2307/3151897

Aaker, J. (1999). The malleable self: The role of self-expression in persuasion. Journal of Marketing Research, 36, 45-57. http://dx.doi.org/10.2307/3151914

Akin, M. (2011). Predicting consumers' behavioral intentions with perceptions of brand personality: A study in cell phone markets. International Journal of Business Management, 6(6), 193-206. http://dx.doi.org/10.5539/ijbm.v6n6p193

Aqueveque, C. (2006). Extrinsic cues and perceived risk: the influence of consumption situation. The Journal of Consumer Marketing, 23(5), 237-247. http://dx.doi.org/10.1108/07363760610681646

Barker, R. (1975). Commentaries on Belk: Situational variables and consumer behavior. Journal of Consumer Research, 2(3), 165. http://dx.doi.org/10.1086/208628

Bauer, H. H., Sauer, N. E., \& Becker, C. (2006). Investigating the relationship between product involvement and consumer decision-making styles. Journal of Consumer Behaviour, 5(4), 342-354. http://dx.doi.org/10.1002/cb.185

Bearden, W., \& Etzel, M. (1982). Reference group influence on product and brand decisions. Journal of Consumer Research, 9, 183-94. http://dx.doi.org/10.1086/208911

Beldona, S., \& Wysong, S. (2007). Putting the "brand" back into store brands: An exploratory examination of store brands and brand personality. The Journal of Product and Brand Management, 16(4), 226-235. http://dx.doi.org/10.1108/10610420710763912

Belk, R. (1975). Situational variables and consumer behavior. Journal of Consumer Research, 2, 157-64. http://dx.doi.org/10.1086/208627

Belk, R. (1988). Possessions and the extended self. Journal of Consumer Research, 15, 139-68. http://dx.doi.org/10.1086/209154

Browne, B., \& Kaldenberg, D. (1997). Conceptualizing self-monitoring: Links to materialism and product involvement. Journal of Marketing Theory and Practice, 5(1), 31-45. http://dx.doi.org/10.1108/07363769710155848

Fitzmaurice, J., \& Comegys, C. (2006). Materialism and social consumption. Journal of Marketing Theory and Practice, 14(4), 287-299. http://dx.doi.org/10.2753/MTP1069-6679140403

Folse, J., Netemeyer, R., \& Burton, S. (2012). Spokescharacters: How the personality traits of sincerity, excitement, and competence help to build equity. Journal of Advertising, 41(1), 17-32. http://dx.doi.org/10.2753/JOA0091-3367410102

Lastovicka, J., \& Gardner, D. (1979). Components of involvement. In J. C. Maloney \& B. Silverman (Eds.), Attitude Research Plays for High Stakes (pp. 53-73). Chicago: American Marketing Association.

Laurent, G., \& Kapferer, J. (1985). Measuring consumer involvement profiles. Journal of Marketing Research, 22(1), 41-53. http://dx.doi.org/10.2307/3151549

Mihic, M., \& Kursan, I. (2010). Assessing the situational factors and impulsive buying behavior: Market management approach. Management: Journal of Contemporary Management Issues, 15(2), 47-66.

Mittal, B. (1995). A comparative analysis of four scales of involvement. Psychology and Marketing, 12(7), 670-71. http://dx.doi.org/10.1002/mar.4220120708

Mowen, J., \& Minor, M. (1998). Consumer behavior. Upper Saddle River, New Jersey: Prentice Hall. 
Petty, R., Cacioppo, J., \& Schumann, D. (1986). Central and peripheral routes to advertising effectiveness: The moderating role of involvement. Journal of Consumer Research, 10, 135-46. http://dx.doi.org/10.1086/208954

Podoshen, J., \& Andrzejewski, S. (2012). An examination of the relationships between materialism, conspicuous consumption, impulse buying, and brand loyalty. Journal of Marketing Theory and Practice, 20(3), 319-333. http://dx.doi.org/10.2753/MTP1069-6679200306

Ratchford, B. (1987). New insights about the FCB grid. Journal of Advertising Research, 27(4), 24-38.

Russell, J., \& Mehrabian, A. (1976). Environmental variables in consumer research. Journal of Consumer Research, 3, 62-63. http://dx.doi.org/10.1086/208652

Schiffman, L., \& Kanuk, L. (1997). Consumer behavior. Upper Saddle River, New Jersey: Prentice Hall.

Sung, Y. (2011). The effect of usage situation on Korean consumers brand evaluation: The moderating role of self-monitoring. Journal of Consumer Behaviour, 10(1), 31-40. http://dx.doi.org/10.1002/cb.344

Tedeschi, J. (1986). Private and public experiences and the self. In Roy F. Baumeister (Ed.), Public self and private self (pp. 1-19). New York: Springer-Verlag.

Traylor, M., \& Joseph, W. (1984). Measuring consumer involvement with products: Developing a general scale. Psychology \& Marketing, 1(2), 65-77. http://dx.doi.org/10.1002/mar.4220010207

Wicker, A. (1975). Commentaries on Belk: Situational variables and consumer behavior. Journal of Consumer Research, 2(3), 165-67. http://dx.doi.org/10.1086/208628

Wilkie, W. (1994). Consumer behavior. New York: John Wiley \& Sons.

Witt, R., \& Bruce, G. (1972). Group influence and brand choice congruence. Journal of Marketing Research, 9 , 440-43. http://dx.doi.org/10.2307/3149312

Wysong, S., Munch, J., \& Kleiser, S. (2002). An investigation into the brand personality construct, its antecedents and its consequences. In Kenneth R. Evans \& Lisa K. Sheer (Eds.), American Marketing Association Winter Educators' Conference: Marketing Theory and Applications (pp. 512-518). Chicago, Illinois.

Zaichkowsky, J. (1985). Measuring the involvement construct. Journal of Consumer Research, 12, 341-52. http://dx.doi.org/10.1086/208520

\section{Appendix}

Appendix A. Scale to Measure the Social Visibility of a Situation

A very social situation / Not a very social situation.

A situation where I have little privacy / A situation where I have some privacy.

A situation in which I am surrounded by many people / A situation in which by I am surrounded by few people, if any.

A situation where I must keep my true emotions in check / A situation where I can reveal my true emotions.

A very public situation / A very private situation.

In this situation, I usually act in the interest of the community (social group). / In this situation, I usually act in the interest of a limited number of people. 
Appendix B. Scale to Measure the Involvement of a Situation

This game would be very important to me.

I would look forward to this game the preceding week.

I would be very involved in this game.

It would be essential for me to watch this game.

Appendix C. The Four Experimental Situations

Situation: High Social Visibility, High Involvement

Your favorite team is playing in the championship game. You are going to watch the game at a party at a friend's house. You decide to buy some beer for the game.

Situation: Low Social Visibility, High Involvement

Your favorite team is playing in the championship game. You are going to watch the game at home by yourself. You decide to buy some beer for the game.

Situation: High Social Visibility, Low Involvement

Your favorite team is playing in a preseason game. You are going to watch the game at a party at a friend's house. You decide to buy some beer for the game.

Situation: Low Social Visibility, Low Involvement

Your favorite team is playing in a preseason game. You are going to watch the game at home by yourself. You decide to buy some beer for the game. 